\title{
Akurasi Diagnostik Fibrosis Hati berdasarkan Rasio Red Cell Distribution Width (RDW) dan Jumlah Trombosit Dibanding dengan Fibroscan pada Penderita Hepatitis B Kronik
}

\author{
Frenky Jones, Juwita Sembiring, Lukman Hakim Zain \\ Divisi Gastroenterologi dan Hepatologi, Departemen Ilmu Penyakit Dalam \\ Fakultas Kedokteran Universitas Sumatera Utara, Medan, Indonesia
}

\begin{abstract}
Abstrak
Hepatitis B kronik merupakan masalah global dan Indonesia termasuk negara yang memiliki prevalensi tinggi. Keterbatasan biopsi hati untuk mendiagnosis fibrosis hati karena invasif membangkitkan penelitian metode noninvasif. Dilakukan penelitian uji diagnostik potong lintang untuk mengetahui akurasi rasio red cell distribution width (RDW) terhadap jumlah trombosit untuk memprediksi derajat fibrosis hati penderita hepatitis B kronik. Terhadap subjek penelitian dilakukan pemeriksaan HBsAg, darah rutin, dan fibroscan di RSUP H. Adam Malik, Medan sejak Januari sampai Maret 2015. Nilai rasio RDW terhadap trombosit dihitung dari hasil pemeriksaan darah rutin. Derajat fibrosis hati dinilai berdasarkan hasil fibroscan dari skala Fo-F4. Prosedur analisis adalah receiver operating characteritic (ROC) dan area under the curve (AUC). Dari 34 kasus, 20 orang termasuk kelompok fibrosis hati ringan-sedang $(\mathrm{F} \leq 2)$ dan 14 orang kelompok fibrosis berat $(\mathrm{F}>2)$. Nilai akurasi sebesar $72,3 \%$ (IK 95\%:84,1-97\%). Dengan nilai cut-off o,0591 didapatkan sensitivitas 71,4\%; spesifisitas 60\%; nilai prediksi positif (NPP) 55,6\%; nilai prediksi negatif (NPN) 75\%; rasio kemungkinan positif (RKP) 1,79; dan rasio kemungkinan negatif (RKN) 0,48. Simpulan, rasio RDW terhadap jumlah trombosit mampu memprediksi derajat fibrosis hati penderita hepatitis B kronik dengan tingkat akurasi sedang $(72,3 \%)$.
\end{abstract}

Kata kunci: Fibroscan, fibrosis hati, hepatitis B kronik, RDW, trombosit

\section{Diagnostic Accuracy of Liver Fibrosis based on Red Cell Distribution Width (RDW) to Platelet Count with Fibroscan in Chronic B Hepatitis}

\begin{abstract}
Chronic hepatitis B is a global problem and Indonesia has a high prevalence. Limitation of liver biopsy as an invasive method, initiates many studies on non invasive diagnosing method for liver fibrosis. The cross sectional study was conducted to determine the accuracy of red cell distribution width (RDW) to platelet count ratio (RPR) in predicting liver fibrosis degree in chronic hepatitis B. HBsAg, complete blood count, and fibroscan were examined in H. Adam Malik Hospital, Medan from January to March, 2015. RPR was calculated. The degree of liver fibrosis assessed by fibroscan on a scale of Fo-F4. The accuracy was evaluated by constructing receiver operating characteritic (ROC) and area under the curve (AUC). From 34 cases, 20 subjects were in mild-moderate liver fibrosis $(\mathrm{F} \leq 2)$ and 14 subjects in severe liver fibrosis ( $\mathrm{F}>2$ ). The accuracy was 72.3\% (95\% CI: 84.1-97\%) with a cut-off value 0.0591 . Sensitivity was $71.4 \%$, specificity $60 \%$, positive predictive value (PPV) $55.6 \%$, negative predictive value (NPV) $75 \%$, positive predictive ratio (PPR) 1.79, and negative predictive ratio (NPR) was 0.48 . RDW to platelet count ratio can predict liver fibrosis grade in chronic hepatitis B with a moderate degree of accuracy (72.3\%).
\end{abstract}

Key words: Chronic hepatitis B, fibroscan, liver fibrosis, platelet, RDW

Korespondensi: Frenky Jones, Divisi Gastroenterologi dan Hepatologi, Departemen Ilmu Penyakit Dalam Fakultas Kedokteran Universitas Sumatera Utara, Medan, Indonesia 


\section{Pendahuluan}

Infeksi karena virus Hepatitis B kronik masih merupakan masalah kesehatan yang global dan diperkirakan sekitar 350 juta orang di dunia terinfeksi virus ini. Indonesia termasuk negara dengan prevalensi hepatitis B termasuk tinggi; sekitar 9,4\% penduduk Indonesia atau sekitar 23 juta penduduk terinfeksi virus hepatitis B. ${ }^{1,2}$ Pada hepatitis kronik terjadi proses destruksi progresif dan regenerasi parenkim hati yang lalu akan berkembang menjadi fibrosis, dapat berkembang menjadi sirosis hati, dan juga dapat berakhir dengan hepatoma. Fibrosis hati merupakan penyebab morbiditas dan mortalitas penyakit hepatitis kronik sehingga diperlukan penentuan derajat fibrosis yang lebih dini untuk menentukan pengobatan yang tepat.

Biopsi hati merupakan suatu gold standard untuk mendiagnosis derajat fibrosis hati. Saat ini banyak penelitian fibrosis hati menggunakan fibroscan sebagai alat diagnostik noninvasif yang memiliki akurasi tinggi yang hampir menyamai biopsi hati dalam mendiagnosis fibrosis hati. Kerusakanpadahatiterbuktidapatmemengaruhi pembentukan trombopoetin yang dikeluarkan oleh hepatosit. Kerusakan hati yang lanjut sering disertai dengan hipersplenisme yang disebabkan karena komplikasi pada hipertensi portal dan juga terjadi sekuestrasi serta penghancuran trombosit dalam limpa. Jumlah trombosit sering dipakai sebagai salah satu biomarker kerusakan hati. Red cell distribution width (RDW) dapat menjadi representasi defisiensi nutrisi (seperti zat besi, vitamin B12, dan asam folat), depresi sumsum tulang, dan inflamasi kronik. Kondisi seperti ini sering didapatkan pada penderita penyakit hati. ${ }^{3-7}$

Peningkatan RDW tersebut secara signifikan sesuai dengan derajat kerusakan pada hati. ${ }^{8}$ Rasio antara RDW dan jumlah platelet dapat memprediksi terjadi fibrosis dan sirosis hati pada hepatitis B yang kronik secara signifikan dengan akurasi relatif tinggi dan lebih superior dibanding dengan metode noninvasif yang lain seperti rasio aspartat aminotransferase (AST) dengan alanin aminotransferase (ALT), indeks rasio AST (aspartat aminotransferase) dengan jumlah sel trombosit, dan juga FIB-4. ${ }^{9}$

Penelitian ini menilai akurasi diagnostik derajat fibrosis hati pada penderita hepatitis $\mathrm{B}$ kronik di RSUP H. Adam Malik berdasarkan rasio red cell distribution width (RDW) terhadap jumlah trombosit dibanding dengan fibroscan.

\section{Metode}

Penelitian uji diagnostik dengan cara potong lintang (cross sectional study) pada penderita hepatitis $\mathrm{B}$ kronik berusia $\geq 18$ tahun dengan HBsAg $(+) \geq 6$ bulan yang dirawat di RSUP $H$. Adam Malik di Medan. Ethical clearence (izin penelitian) telah diperoleh dari Komite Etik Penelitian dalam bidang Kesehatan Fakultas Kedokteran Universitas Sumatera Utara.

Kriteria eksklusi adalah pasien tidak bersedia diperiksa, ada koinfeksi HIV atau HCV, sirosis hati dalam stadium dekompensata, hepatoma, gagal jantung, demam berdarah dengue/DBD, purpura trombositopenia idiopatik, dan riwayat transfusi darah ( $\leq 4$ bulan untuk transfusi yang mengandung eritrosit; $\leq 2$ minggu untuk yang mengandung trombosit).

Pada subjek penelitian dilakukan anamnesis data identifikasi dan data penyakit, pemeriksaan tanda vital dan fisis, pemeriksaan laboratorium HbsAg, RDW dan trombosit, serta pemeriksaan fibroscan. Akurasi rasio RDW terhadap jumlah sel trombosit untuk mendiagnosis fibrosis hati dianalisis dengan area under the curve (AUC) setelah didapat cut-off nilai rasio RDW terhadap jumlah trombosit menggunakan kurva receiver operating characteristic (ROC). Nilai diagnostik yang lain, yaitu sensitivitas, spesifisitas, positive predictive value (PPV), dan negative predictive value (NPV) ditentukan dengan prosedur kurva receiver operating characteristic (ROC).

\section{Hasil}

Dari 51 orang penderita hepatitis B kronik, 34 orang memenuhi kriteria inklusi dan tidak termasuk dalam kriteria eksklusi. Responden laki-laki sebanyak 23 orang dengan usia ratarata subjek 37,94 tahun. Hasil pemeriksaan RDW rata-rata $14,43 \%$ dan trombosit rata-rata 208.680/ $\mathrm{mm}^{3}$. Rasio RDW terhadap trombosit rata-rata 0,09 . Pemeriksaan fibroscan rata-rata $12,72 \mathrm{kPa}$. Derajat fibrosis ringan-sedang $(\mathrm{F} \leq 2)$ pada 20 orang, fibrosis berat $(\mathrm{F}>2)$ pada 14 orang. Dari 34 sampel, kelompok ringan-sedang terdiri atas 17 orang Fo-1 dan 3 orang F2. Pada kelompok berat, 5 orang F3 dan 9 orang F4.

Analisis kurva ROC menghasilkan area di bawah kurva (AUC) ROC adalah sebesar 72,3\% (IK 95\%: 84,1-97\%). Rasio RDW/trombosit dalam penelitian ini mempunyai kemampuan yang sedang untuk dapat memprediksi derajat fibrosis $(\mathrm{p}=0,029$ dengan $\mathrm{AUC}>70 \%)$. 
Tabel 1 Karakteristik Subjek Penelitian

\begin{tabular}{|c|c|c|}
\hline \multicolumn{2}{|c|}{ Karakteristik Subjek } & $n=34$ \\
\hline \multicolumn{3}{|c|}{ Jenis kelamin, (n) } \\
\hline \multicolumn{2}{|c|}{ Laki-laki } & 23 \\
\hline \multicolumn{2}{|c|}{ Perempuan } & 11 \\
\hline \multicolumn{2}{|c|}{ Usia, rata-rata (SB), tahun } & $37,94(12,44)$ \\
\hline \multicolumn{2}{|c|}{ RDW, rata-rata (SB) } & $14,43(2,68)$ \\
\hline \multicolumn{2}{|c|}{ Trombosit, rata-rata (SB), ribu/ $\mathrm{mm}^{3}$} & $208.680(76.660)$ \\
\hline \multicolumn{2}{|c|}{ RDW/trombosit, rata-rata (SB) } & $0,09(0,1)$ \\
\hline \multicolumn{2}{|c|}{ Fibroscan, rata-rata (SB), kPa } & $12,72(13,38)$ \\
\hline \multicolumn{3}{|c|}{ Derajat fibrosis hati, $\mathrm{n}$} \\
\hline Fo-1 & Ringan-sedang & 17 \\
\hline $\mathrm{F} 2$ & & 3 \\
\hline $\mathrm{F}_{3}$ & Berat & 5 \\
\hline $\mathrm{F}_{4}$ & & 9 \\
\hline
\end{tabular}

Berdasarkan atas kurva sensitivitas dan juga spesifisitas (Gambar 3) diperoleh nilai cut-off untuk rasio RDW/trombosit adalah 0,0591 . Dengan cut-off point 0,0591 didapatkan nilai sensitivitas Rasio RDW/trombosit adalah 71,4\% dan spesifisitas 60\%. Nilai prediksi positif (NPP) rasio $\mathrm{RDW} /$ trombosit sebesar $55,6 \%$ dan nilai prediksi negatif (NPN) adalah $75 \%$; sedangkan rasio kemungkinan positif adalah 1,79 dan rasio kemungkinan negatif adalah 0,48 .

\section{Pembahasan}

Beberapa model diagnostik fibrosis hati noninvasif pada penyakit hati kronik yang telah dipublikasikan, seperti Fibro index dan FIB-4 lebih banyak diterapkan pada hepatitis $\mathrm{C}$ kronik dibanding dengan hepatitis B kronik. ${ }^{10,11}$ Model

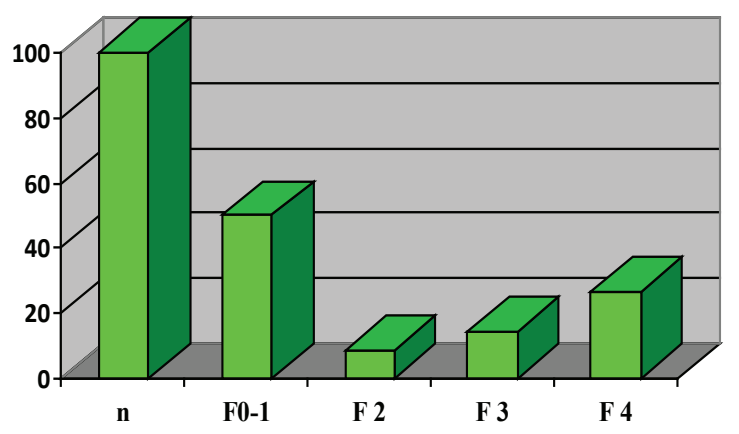

Gambar 1 Diagram Persentase Derajat Fibrosis Hati diagnostik seperti AST/ALT rasio (AAR), APRI score, Fibro test, dan FIB-4 tersebut sudah diterapkan untuk memprediksi fibrosis hati, namun masih sulit untuk dipraktikkan oleh para klinisi ${ }^{12}$ karena pemeriksaan beberapa marker biokimia tidak sederhana atau perlu program komputer khusus untuk perhitungan model diagnostik.

Fibroscan terbukti sudah dianggap sebagai alat diagnostik yang mampu mengimbangi biopsi hati secara holistik dengan mempertimbangkan kelemahan yang biasa terjadi dalam pelaksanaan pemeriksaan fibrosis hati. Abdelmaksoud dkk. ${ }^{17}$ mendapatkan kesamaan hasil pada pemeriksaan fibroscan dengan biopsi hati pada hepatitis $\mathrm{C}$ kronik, terutama pada derajat fibrosis hati $\mathrm{F}_{3}{ }^{17}$

Pada fibrosis hati sering kali didapatkan kondisi sebagai trombositopenia. Ada berbagai

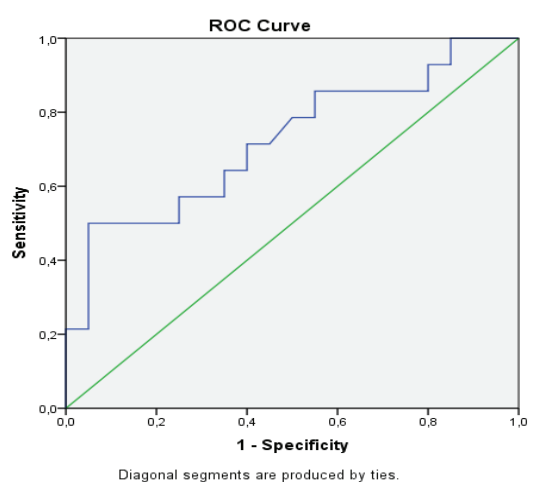

Gambar 2 Kurva ROC dari Rasio RDW/ Trombosit untuk Memprediksi Derajat Fibrosis Hati 


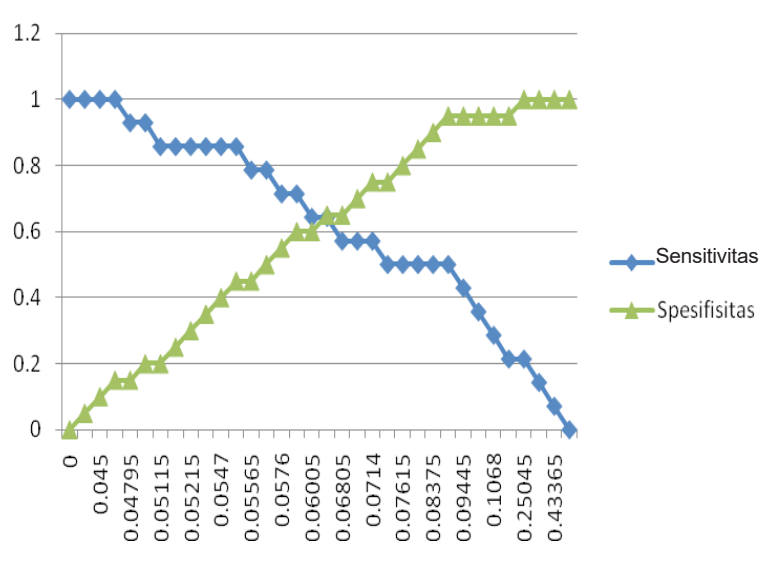

Gambar 3 Kurva Sensitivitas dan Spesifisitas Rasio RDW/Trombosit terhadap Derajat Fibrosis Hati

kemungkinan penyebabnya, di antaranya adalah sekuestrasi dan juga penghancuran sel trombosit dalam limpa serta berkurangnya pembentukan trombopoetin akibat dari kerusakan pada hati. ${ }^{2}$ Terdapat hubungan antara derajat fibrosis hati pada hepatitis yang kronik dan penurunan kadar trombopoetin serta jumlah trombosit. ${ }^{13}$ Juga didapatkan hubungan keparahan penyakit hati dengan penurunan jumlah trombosit, terutama pada sirosis hati. ${ }^{14}$

Selain kondisi trombositopenia, juga sering didapatkan peningkatan red cell distribution width (RDW). Lou dkk. ${ }^{8}$ mendapatkan hasil peningkatan red cell distribution width (RDW) yang signifikan pada penderita hepatitis B sesuai derajat keparahan penyakit hati. ${ }^{8}$ Xu dkk..$^{15}$ mendapat hasil bahwa red cell distribution width (RDW) dapat dipergunakan untuk memprediksi fibrosis hati dan nekro inflamasi pada pasien hepatitis B bila dikombinasi dengan marker biokimia lain. ${ }^{15}$ Huang dkk. ${ }^{16}$ menyatakan bahwa red cell distribution width (RDW) meningkat pada hepatitis B kronik dan berpotensi sebagai salah satu indeks keparahan penyakit hepatitis B kronik. Untuk membuat model prediksi baru dengan komponen jumlah trombosit dan red cell distribution width (RDW), Chen dkk. ${ }^{9}$ meneliti dengan komponen pemeriksaan laboratorium darah sederhana dan menggunakan rumus yang sederhana pula, disebut RDW to platelet ratio (RPR formula). ${ }^{9}$

\section{RDW to Platelet Ratio $(\mathrm{RPR}$ formula $)=$ Red cell distribution width (RDW) (\%) \\ Jumlah trombosit $\left(10^{3} / \mathrm{mm}^{3}\right)$}

RDW to platelet ratio atau RPR formula dibanding dengan pemeriksaan biopsi hati pada penyakit hepatitis B kronik, ternyata hasilnya signifikan dapat memprediksi fibrosis hati pada pasien hepatitis B kronik; ${ }^{9}$ tingkat akurasi untuk fibrosis hati sebesar 82,5\% dan untuk sirosis hati sebesar $88,4 \%$; dengan sensitivitas $63,1 \%$; spesifisitas 85,5\%; PPV sebesar 77,4\%; dan NPV 74,7\% untuk fibrosis hati dan sensitivitas 73,7\%; spesifisitas 93,0\%; PPV 60,8\%; dan NPV 96,0\% untuk sirosis hati. Model prediktif ini mempunyai tingkat akurasi yang lebih besar dibanding dengan AST/ALT Rasio (AAR), APRI score, dan FIB-4.

Penelitian ini memakai formula yang sama ${ }^{9}$ dilakukan analisis statistik untuk menentukan tingkat akurasinya dibanding dengan fibroscan.

Penelitian ini melibatkan 51 orang penderita hepatitis B kronik, 34 orang memenuhi kriteria inklusi dan tidak termasuk eksklusi. Jumlah sampel terbatas karena alat diagnostik fibroscan di RSUP H. Adam Malik Medan rusak setelah penelitian berjalan beberapa bulan. Dilakukan pemeriksaan laboratorium darah sederhana red cell distribution width (RDW) dan trombosit untuk menghitung RPR dengan formula:

$$
\mathrm{RPR}=\frac{\text { Red cell distribution width (RDW) }(\%)}{\text { Jumlah trombosit }\left(10^{3} / \mathrm{mm}^{3}\right)}
$$

Hasil perhitungan ini lalu dibanding dengan hasil fibroscan.

Tabel 2 Sensitivitas, Spesifisitas, Positive dan Negative Predictive Value Rasio RDW/

\begin{tabular}{|c|c|c|c|c|c|c|c|c|}
\hline \multirow[b]{2}{*}{ Guci Index } & \multicolumn{2}{|c|}{ Derajat Fibrosis } & \multirow[b]{2}{*}{ Sensitivitas } & \multirow[b]{2}{*}{ Spesifisitas } & \multirow[b]{2}{*}{ NPP } & \multirow[b]{2}{*}{ NPN } & \multirow[b]{2}{*}{$\mathbf{R K P}$} & \multirow[b]{2}{*}{ RKN } \\
\hline & Berat & $\begin{array}{c}\text { Ringan- } \\
\text { Sedang } \\
\end{array}$ & & & & & & \\
\hline$\geq 0,0591$ & 10 & 8 & $71,4 \%$ & $60 \%$ & $55,6 \%$ & $75 \%$ & 1,79 & 0,48 \\
\hline$<0,0591$ & 4 & 12 & & & & & & \\
\hline
\end{tabular}
Trombosit terhadap Derajat Fibrosis 
Perhitungan dengan cara mempergunakan prosedur ROC mendapatkan tingkat akurasinya sebesar 72,3\% (IK 95\%: 84,1-97\%). Rasio $\mathrm{RDW} /$ trombosit dalam penelitian ini memiliki kemampuan sedang untuk memprediksi derajat fibrosis ( $\mathrm{p}=\mathrm{0}, 029$ dengan $\mathrm{AUC}>70 \%){ }^{16}$

Hasil penelitian ini memiliki tingkat akurasi sedang (AUC > 70-80\%), lebih rendah dibanding dengan penelitian dilakukan sebelumnya yang tingkat akurasinya adalah baik (AUC $>80-$ 90\%). ${ }^{9}$ Jumlah sampel merupakan kelemahan penelitian ini sehingga diperlukan penelitian lebih lanjut dengan skala yang lebih besar.

Dengan nilai cut-off point 0,0591 didapatkan nilai sensitivitas rasio $\mathrm{RDW} /$ trombosit $71,4 \%$ dan spesifisitasnya $60 \%$. Nilai prediksi positif (NPP) rasio RDW/trombosit sebesar 55,6\% dan nilai prediksi negatif (NPN) adalah $75 \%$. Rasio kemungkinan positif adalah 1,79 dan rasio kemungkinan negatif adalah 0,48 .

Rasio antara RDW/trombosit dengan tingkat akurasi yang sedang sebesar $72,3 \%$ belum dapat menggantikan fibroscan dan biopsi hati sebagai alat diagnostik baku untuk menentukan derajat fibrosis hati. Rasio antara RDW terhadap jumlah trombosit dapat bermanfaat dan dapat dipakai pada tempat yang belum mempunyai fasilitas fibroscan sebagai skrining untuk dapat prediksi penderita yang sudah mengalami fibrosis hati. Selain itu, bagi pasien-pasien yang sudah pernah menjalani pemeriksaan fibroscan, pemeriksaan rasio antara RDW dan jumlah sel trombosit dapat digunakan untuk pemantauan sebelum pemeriksaan ulang fibroscan dapat dilakukan.

\section{Simpulan}

Rasio red cell distribution width (RDW) terhadap jumlah trombosit (RPR=RDW to Platelet Ratio) merupakan model perhitungan prediksi derajat fibrosis hati pada penderita hepatitis B yang kronik dengan tingkat akurasi sedang (72,3\%). Pada pasien-pasien yang belum dapat menjalani pemeriksaan fibroscan, rasio antara RDW dan jumlah trombosit dapat dipergunakan sebagai skrining prediksi fibrosis hati pada penderita hepatitis B kronik.

\section{Daftar Pustaka}

1. Badan Penelitian dan Pengembangan Kesehatan. Riset Kesehatan Dasar 2007. Jakarta: Departemen Kesehatan Republik Indonesia; 2008.
2. Pradella $\mathrm{P}$, Bonetto $\mathrm{S}$, Turchetto $\mathrm{S}$, Uxa L, Comar C, Zorat F, dkk. Platelet production and destruction in liver cirrhosis. J Hepatol. 2011;54(5):894-900.

3. Grigorescu M. Non invasive biochemical markers of liver fibrosis. J Gastrointestin Liver Dis. 2006;15(2):149-59.

4. Lee KG, Seo YS, An H, Um SH, Jung ES, Keum $\mathrm{B}, \mathrm{dkk}$. Usefulness of non invasive markers for predicting liver cirrhosis in patients with chronic hepatitis B. J Gastroenterol Hepatol. 2010;25(1):94-100.

5. Poynard T, Morra R, Ingiliz P, Imbert-Bismut F, Thabut D, Messous D, dkk. Assessment of liver fibrosis: noninvasive means. Saudi J Gastroenterol. 2008;14(4):163-73.

6. Kim SU, Han KH, Ahn SA. Transient elastography in chronic hepatitis B: an Asian perspective. World J Gastroenterol. 2010;16(41):5173-80.

7. Ledinghen VD, Vergniol J. Transient elastography (fibroscan). Gastroenterol Clin Biol. 2008;32:58-66.

8. Lou YF, Wang MY, Mao WL. Clinical usefulness of measuring red blood cell distribution width in patients with hepatitis B. PLoS ONE. 2012;7(5):1-6.

9. Chen B, Ye B, Zhang J, Ying L, Chen Y. RDW to platelet ratio: a novel noninvasive index for predicting hepatic fibrosis and cirrhosis in chronic hepatitis B. PLoS ONE. 2013;8(7):e68780.

10. Koda M, Matunaga Y, Kawakami M, Kishimoto Y, Suou T, Murawaki Y. FibroIndex, a practical index for predicting significant fibrosis in patients with chronic hepatitis C. Hepatology. 2007;45(2):297306.

11. Vallet PA, Mallet V, Pol S. FIB-4: a simple, inexpensive, and accurate marker of fibrosis in HCV-infected patients. Hepatology. 2006; 44:769-70.

12. Castera L. Non invasive methods to assess liver diseases in patients with hepatitis B or C. Gastroenterology. 2012; 142:1293-302.

13. Sembiring J. Correlation between thrombopoietin serum level and liver fibrosis in chronic hepatitis patients. Department of Internal Medicine, Faculty of Medicine University of North Sumatera/Adam Malik Hospital, Medan. Indon $\mathrm{J}$ Gastroenterol Hepatol Digestive Endoscopy. 2010;11:3.

14. Nwokediuko SC, Ibegbulam O. Quantitative 
platelet abnormalities in patients with hepatitis B virus-related liver diseases. Gastroenterol Res. 2009;2(6):344-9.

15. Xu WS, Qiu XM, Ou QS, Liu C, Lin JP, Chen HJ, dkk. Red blood cell distribution width levels correlate with liver fibrosis and inflammation: a non invasive serum marker panel to predict the severity of fibrosis and inflammation in patients with hepatitis B. Medicine (Baltimore). 2015;94(10):e612.

16. Huang R, Yang C, Wu K, Cao S, Liu Y, Su R, dkk. Red cell distribution width as a potential index to assess the severity of hepatitis B virus related liver diseases. Hepatol Res. 2014;44(14):E464-70.

17. Abdelmaksoud AHK, Taha MES, Kassas ME, Mahdy RE, Mohamed GDE, Samy HA. Prospective comparison of transient elastography and liver biopsy for the assessment of fibrosis in chronic hepatitis $\mathrm{C}$ infection. Egyptian J Radiol Nuclear Med. 2015;46:293-7. 